Article

\title{
Integrated Reporting as an Academic Research Concept in the Area of Business
}

\author{
José Navarrete-Oyarce ${ }^{1}\left(\right.$, Juan Alejandro Gallegos ${ }^{2, *}$, Hugo Moraga-Flores ${ }^{3}$ and José Luis Gallizo ${ }^{4}$ \\ 1 Facultad de Economía y Negocios, Universidad Andrés Bello, Concepción 4030000, Chile; \\ jose.navarrete@unab.cl \\ 2 Facultad de Ciencias Económicas y Administrativas, Departamento de Auditoría y Sistemas de Información, \\ Universidad Católica de la Santísima Concepción, Concepción 4030000, Chile \\ 3 Facultad de Ingeniería, Universidad Andrés Bello, Santiago 7591538, Chile; hug.moraga@uandresbello.edu \\ 4 Departamento de Administración de Empresas, Universidad de Lleida, 25002 Lleida, Spain; \\ joseluis.gallizo@udl.cat \\ * Correspondence: jgallegos@ucsc.cl
}

check for

updates

Citation: Navarrete-Oyarce, J.; Gallegos, J.A.; Moraga-Flores, H.; Gallizo, J.L. Integrated Reporting as an Academic Research Concept in the Area of Business. Sustainability 2021, 13, 7741. https://doi.org/10.3390/ su13147741

Received: 2 June 2021

Accepted: 1 July 2021

Published: 12 July 2021

Publisher's Note: MDPI stays neutral with regard to jurisdictional claims in published maps and institutional affiliations.

Copyright: (c) 2021 by the authors. Licensee MDPI, Basel, Switzerland. This article is an open access article distributed under the terms and conditions of the Creative Commons Attribution (CC BY) license (https:/ / creativecommons.org/licenses/by/ $4.0 /)$.

\begin{abstract}
Recent financial scandals and the global financial crisis have generated numerous criticisms of the value and use of annual financial and sustainability reports prepared by companies. This has generated the elaboration and use of a new model of corporate-information reporting that considers strategic, social, economic, and environmental aspects. This study synthesizes the knowledge of the use of integrated reporting as a source of information, and bibliometrically analyzes of 268 articles published in the Web of Science database in 2011-2019. Results show that $77.6 \%$ of the academic articles were from developed countries, and the five most influential countries are Italy, South Africa, Australia, the United Kingdom, and the United States. Results show that the development of this type of research is scarce in emerging economies. The most influential authors are García, Rodríguez, and De Villiers. A high level of interconnections is observed in used keywords, of which the most used are 'sustainability' and 'management'. Lastly, this article contributes to the international discussion on integrated reporting by carrying out a structured review of the literature, highlighting previous research.
\end{abstract}

Keywords: integrated reporting; web of science; disclosure; bibliometric

\section{Introduction}

Recent financial scandals and the global financial crisis have generated numerous criticisms of the value and use of the annual financial and sustainability reports prepared by companies [1-3]. The scarce strategic evaluation of their results $[4,5]$ has affected the adequate evaluation of true drivers of corporate value [6].

This, in turn, has generated the elaboration and use of a new model of reporting of corporate information that considers strategic, social, economic, and environmental aspects $[5,7,8]$. Known as integrated reporting, this new initiative in reporting addresses current limitations in the communication of traditional financial reports that tend to be criticized for their length and lack of articulation [9]. For this reason, integrated reporting strengthens the provision of nonfinancial information, and increases the transparency of organizations and their capacity to create value [10-14].

Because integrated reporting was first prepared and published less than a decade ago, empirical evidence with respect to its value is relatively scarce. In particular, the majority of undertaken studies considered the effect in South African companies, where the preparation of integrated reporting is obligatory $[15,16]$. However, and in spite of the strategic value of integrated reporting, few studies have looked at its value in other countries, where integrated reporting is voluntarily put together and published [7,17-19]. For this reason, this article conducts a structured literature review of publications related 
to integrated reporting through bibliometric and scientometric analysis. This research significantly contributes to the current literature by synthesizing knowledge and providing a discussion on conducted research on integrated reporting, offering researchers updated bibliometric analysis to support future research.

The rest of this paper is arranged as follows. Section 2 reviews the related literature. Section 3 presents the data and methods. Section 4 presents and discusses the results. Section 5 concludes the article.

\section{Literature Review}

The need to prepare information to adequately evaluate company performance is usually voluntary and mainly seen through the lens of each organization due to the absence of a general norm [20-22]. Thus, a pilot program was initiated in 2011 that sought to create an adequate normative framework $[19,23,24]$. This, over time, began to massively expand at the international level [22].

Integrated reporting arose out of the requirement for companies to provide information about their financial results, corporate governance, and sustainability, given that an enterprise provides strategic information that facilitates the evaluation and participation of diverse stakeholders [25-28]. In spite of the value of this information, there are organizations that regard this type of initiative as an unnecessary cost rather than a moral obligation to provide better information to their stakeholders [29,30]. There is evidence of better internal decision making through the use of integrated reporting [31]. However, there is no conclusive information in terms of its value with respect to proposals for external improvements from interest groups [32]. This is despite evidence showing that the use of integrated reporting reduces information asymmetries, allowing for participants in the capital market to make more precise cash, flow predictions $[9,33,34]$.

Integrated reporting adopts a flexible approach in its preparation, permitting adequate comparability between organizations with respect to relevant information to communicate, concentrating on the fundamental concepts presented in Table 1 [35-37].

Table 1. Guidelines for preparing integrated-reporting statement.

\begin{tabular}{lll}
\hline \multicolumn{1}{c}{ Guiding Principles } & \multicolumn{1}{c}{ Content Elements } & Fundamental Concepts \\
\cline { 1 - 2 } Strategic focus and future orientation. & $\begin{array}{l}\text { Organizational overview and external } \\
\text { environment. }\end{array}$ & \\
\hline Connectivity of information. & Governance. & Value creation for the organization \\
Stakeholder relationships. & Business model. & and for other stakeholders. \\
Materiality. & Risks and opportunities. \\
Conciseness. & Strategy and resource allocation. & \\
Reliability and completeness. & Performance. & \\
\hline Consistency and comparability. & Outlook. & Basis of preparation and presentation. \\
\hline
\end{tabular}

Source: International Integrated Reporting Council (2013).

Specifically, the guiding principles for preparing integrated reporting show the fundamental concepts that sustain the preparation and presentation of the report. The content elements show the required content that integrated reporting must report, and the fundamental concepts indicate the value and requirements of the prepared information [35].

The value of information through integrated reporting to stakeholders is an important aspect to consider [38]. For this reason, integrated reporting provides greater transparency to business management, allowing for greater and better sustainability, linking financial performance and strategic information in a single report [38,39]. Since 2013, the International Integrated Reporting Council has recommended using simple, concise, and useful language for the decision-making process with a strategic focus for the organization's stakeholders $[11,38]$. Therefore, integrated reporting aims to improve communication between internal and external stakeholders to the organization, from organizational strategy 
to financial performance $[16,40,41]$. Ref. [34] analyzed the relationship between the degree of disclosure of the Integrated Report, measured through a compliance index and financial performance, through Tobin's $Q$, using variables such as return on assets, indebtedness, and company size. Additionally, [42] demonstrated a positive relationship between the issuance of the Integrated Report and ROIC. Lastly, [43] determined the relationship between the Integrated Report and earnings per share in a group of companies in South Africa. In addition, there is a strong positive association between company valuation and Integrated Reporting in large, complex companies with high intangible assets and multiple business segments [34].

Ecological disasters and recent financial crises that revealed the vulnerability of the market as a regulatory entity have motivated a reconsideration of the requirements for the disclosure of strategic, social, environmental, and financial information for the better control of companies [44]. The evolution of integrated reporting from a financial to a strategic vision is not always conclusive [44,45]. Table 2 shows a development of the evolution and emphasis of prepared information by companies up to the current integrated reporting.

Table 2. Developments in the reporting of financial and nonfinancial information by companies.

\begin{tabular}{lll}
\hline \multicolumn{1}{c}{ Decade } & \multicolumn{1}{c}{ Report } & \multicolumn{1}{c}{ Focus and Emphasis } \\
\hline Before the 1970s & Financial reporting & Only financial vision. \\
\hline Between 1970s and 1980s & $\begin{array}{l}\text { Financial reporting and social or } \\
\text { environmental reports. }\end{array}$ & $\begin{array}{l}\text { Financial vision isolated from social and } \\
\text { environmental information. }\end{array}$ \\
\hline \multirow{2}{*}{ 1990s } & $\begin{array}{l}\text { Financial reporting and specialized } \\
\text { sustainability reports combining social and } \\
\text { environmental information. }\end{array}$ & $\begin{array}{l}\text { Financial vision isolated from sustainability } \\
\text { information. However, ecological and social } \\
\text { dimensions acquire great value. }\end{array}$ \\
\hline $2000 \mathrm{~s}$ & $\begin{array}{l}\text { Preparation of partially integrated } \\
\text { sustainability and financial reporting. }\end{array}$ & $\begin{array}{l}\text { Greater emphasis on financial vision and } \\
\text { integration with nonfinancial information. }\end{array}$ \\
\hline \multirow{2}{*}{ Nowadays } & $\begin{array}{l}\text { Preparation of integrated reporting with a } \\
\text { holistic view of the organization. }\end{array}$ & $\begin{array}{l}\text { Balanced emphasis on financial, ecological, } \\
\text { and social dimensions that enable the } \\
\text { sustainability of the company }\end{array}$ \\
\hline
\end{tabular}

Resource: Adapted from [44].

Despite the need to reveal this type of information for decision making, studies on the effects of integrated reporting are limited $[19,46]$, although numerous studies highlighted the need to increase the research due to the existence of inconclusive results [46]. This is in spite of its increasing use in various countries and industries [47,48].

Refs. $[36,49]$ found that there is growing utilization of integrated reporting in South Africa and Sri Lanka, but both studies suggested that there are concerns with respect to the content and quality of these reports. On the one hand, [3,50,51] found evidence of a significant and positive effect between revealed information in integrated reporting and financial performance. On the other hand, [52], using data from 35 countries, found that revealed information by integrated reporting reduces agency costs and problems. They also found that the efficacy of integrated reporting is greater in companies with a larger degree of diversification. However, [36], and [19] found no evidence of a positive and significant effect between revealed information in integrated reporting and financial performance.

Inconclusive results in the research with respect to the use and value of integrated reporting suggests the need for bibliometric analysis that synthesizes the knowledge and adequately discusses published results in principal scientific journals (Web of Science, WoS) in support of future research.

\section{Methodology}

\subsection{Bibliometric Analysis}

A literature review is an academic exercise that must have a logical and planned structure, and it requires proof-based quantitative and qualitative methods [53]. In general, 
there are two methodological approaches to quantify the flow of information. The first is to utilize a complete publication or its characteristics, such as citations, keywords, and author's name, which is known as scalar techniques. The second is analysis that identifies links among objects, their networks, and co-occurrences [54].

To obtain a global vision of the effect of integrated reporting, in this study, we utilized a combination of both scalar and analytical techniques. Bibliometric indicators used for analysis are: the total number of publications, total number of citations, journals with the largest amount of scientific production on the concept of integrated reporting, institutions with the largest amount of scientific production according to the affiliation of their authors, most influential authors according to the number of citations of their publications, and countries with the largest amount of scientific production according to the affiliation of authors. In addition, this study analyzes the bibliometric map with the concept of integrated reporting. In this way, it was possible to design a detailed map of the key concepts on the basis of data frequency and their respective clusters. Results were analyzed using SPSS version 24 software, which allowed for us to analyze the frequencies of terms, and to construct relationships of these terms to generate matrices and vectors applied to each type of bibliometric study. Furthermore, analysis of social networks with a basis in graph theory, also known as knowledge maps, was performed using VOSviewer version 1.6.15 software, which allowed for us to construct and view maps of bibliometric networks with a certain ease of use [55]. The free version of the software can be downloaded from https: / / www.vosviewer.com/ (accessed date 16 November 2020).

\subsection{Data Collection}

To carry out this study, the concept of integrated reporting was analyzed from the WoS Core Collection database from 1975 to 2019, taking the data from the database updated to 9 June 2020. We reduced the search to articles published in the 'Business and Economics' category, as this corresponds to the area of knowledge most in accordance with the use of integrated reporting, allowing for an appropriate evaluation of an organization's business model and its value-creation process, enabling stakeholders to make an informed assessment of the company's capacity to create current and future value [56]

The WoS database is the world's principal search platform for scientific citations and analytical information, and it has been used in thousands of academic articles in recent decades [57,58]. The WoS database is the property of Clarivate Analytics. It provides all publications and corresponding citations for more than 34,000 professional journals that comprise the nucleus of the international serialized scientific literature in many areas of knowledge [59], and has a longer time lapse than that of other databases [60].

All related information, from the first article published on the concept of integrated reporting in 2011 to 2019, was exported in plain-text format and in the format of commaseparated values, which contain bibliographic, keyword, and citation information, among others. As a result, 268 publications, cited 5215 times, were obtained and analyzed in this study.

\section{Results}

First, we developed descriptive analysis to study the structure of the literature in the field through analyzing publications, citations, authors, institutions, countries, and journals.

\subsection{Distribution of Articles and Citations over Time}

Table 3 shows the evolution of articles related to the concept of integrated reporting between 1975 and 2019, with 268 articles temporally spaced between 2011 and 2019. The first published article was by [61] because the concept began to be researched in greater depth in that year, considering that the international framework for integrated reporting dates back to 2013 [37]. This explains a growing number of new articles since 2015, reaching 34 publications and 1257 citations. 
Table 3. Number of articles published per year.

\begin{tabular}{ccc}
\hline Year & Number of Published Articles & Number of Citations \\
\hline 2019 & 87 & 194 \\
2018 & 50 & 444 \\
2017 & 52 & 995 \\
2016 & 28 & 719 \\
2015 & 34 & 1257 \\
2014 & 11 & 968 \\
2013 & 3 & 417 \\
2012 & 2 & 101 \\
2011 & 1 & 99 \\
Total & 268 & 5215 \\
\hline
\end{tabular}

Source: data from Web of Science (2019).

In addition, a growing level of new articles can be observed from 2011 to 2019, reaching a total of 87 articles in 2019, which shows how recent the topic is, with a total of 194 citations. This greater interest in the literature is in accordance with the obtained results by [22]. Furthermore, an increasing level of new articles is observed, reaching a total of 87 articles in 2019 and 194 citations compared to 2011, when only one article was published. This demonstrates the topicality and importance of this research topic.

The last 6 years contain a total of 262 articles, which corresponds to $97.8 \%$ of published articles and $68.3 \%$ of the total citations. To estimate a growth rate that considers the years of research, $A R T$ (Year $)=\alpha+\beta$ Year ${ }_{t}+\varepsilon_{t}$, was used. Citations grew by 10.05 per year with a determination coefficient $R^{2}$ of $88.24 \%$. (See Figure 1 )

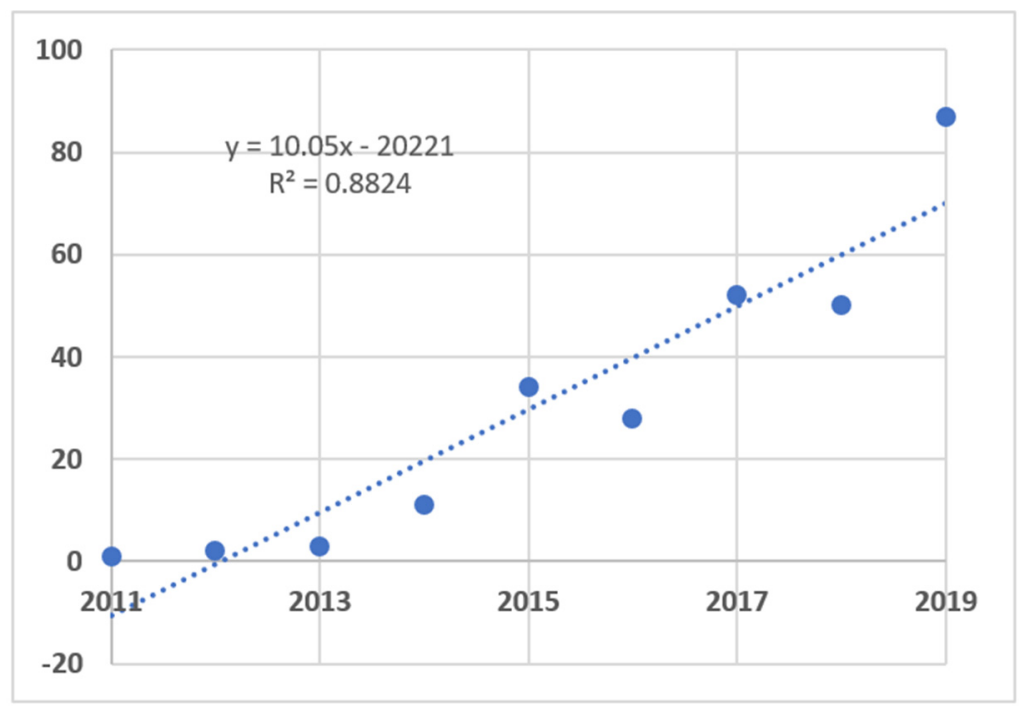

Figure 1. Growth of scientific production. Source: data from Web of Science (2019).

Table 4 shows details of the citations made per year. In total, 41 articles were not cited, equivalent to $15.3 \%$ of the total; 199 articles had fewer than 50 citations, which corresponds to $74.25 \%$ of undertaken studies; 17 articles had between 50 and 99 citations, corresponding to $6.34 \%$ of analyzed articles; 10 articles had between 100 and 199 citations, with $3.73 \%$ of total citations; and 1 article had 200 or more citations, which was $0.37 \%$ of the total. 
Table 4. General structure of citations per article.

\begin{tabular}{ccc}
\hline Number of Citations & Number of Articles & Percentage (\%) \\
\hline 200 or more citations & 1 & 0.37 \\
Between 100 and 199 citations & 10 & 3.73 \\
Between 50 and 99 citations & 17 & 6.34 \\
Between 1 and 50 citations & 199 & 74.25 \\
0 citations & 41 & 15.30 \\
Total & 268 & 100.00 \\
\hline
\end{tabular}

Source: prepared by the authors with data from Web of Science (2019).

In detail, of the total of 268 articles published in 2019, 40 are highlighted given that together they represent the Hirsch or $h$ index [62]. This index favors authors with a long trajectory that publish a continual and above-average flow of work. In total, 40 articles had more than 40 citations, thus constituting the publications of greatest impact in the body of all studied works. From these articles, a paper written by [25] accounts for $3.5 \%$ of the total citations on the topic with 205 references; the article was published in the Accounting Auditing and Accountability Journal by Emerald Group Publishing. In this article, the authors synthesize knowledge of the research on accounting and auditing in the emerging field of integrated reporting, and propose a broad program for future research in this sphere. This result is similar to that proposed by [46], due to the existence of inconclusive results on the benefits of using integrated reporting in corporate decision making.

The second most cited article is that of [28], with 187 citations, which account for $3.01 \%$ of the total citations; it was published in Corporate Social Responsibility and Environmental Management by Wiley. In the article, the authors established that several major companies introduced an integrated-reporting system, which coherently summarizes the available information, thereby making stakeholders participants in business management for data spanning 568 companies from 15 countries for 2008-2010. For greater detail on the most influential articles, Table 5 provides a summary of 12 articles with more than 100 citations.

Table 5. Articles in scientific production with most citations.

\begin{tabular}{|c|c|c|c|c|c|}
\hline Ranking & Author & Year & Title & Journal & Citations \\
\hline 1 & $\begin{array}{l}\text { De Villiers, Charl; Rinaldi, } \\
\text { Leonardo; Unerman, } \\
\text { Jeffrey }\end{array}$ & 2014 & $\begin{array}{l}\text { Integrated reporting: } \\
\text { Insights, gaps and an } \\
\text { agenda for } \\
\text { future research }\end{array}$ & $\begin{array}{l}\text { Accounting Auditing and } \\
\text { Accountability Journal }\end{array}$ & 205 \\
\hline 2 & $\begin{array}{c}\text { Frías-Aceituno, Jose V.; } \\
\text { Rodríguez-Ariza, Lazaro; } \\
\text { García-Sánchez, I. M. }\end{array}$ & 2013 & $\begin{array}{l}\text { The role of the board in } \\
\text { the dissemination of } \\
\text { integrated corporate } \\
\text { social reporting }\end{array}$ & $\begin{array}{l}\text { Corporate Social } \\
\text { Responsibility and } \\
\text { Environmental } \\
\text { Management }\end{array}$ & 185 \\
\hline 3 & Flower, John & 2015 & $\begin{array}{l}\text { The International } \\
\text { Integrated Reporting } \\
\text { Council: A story } \\
\text { of failure }\end{array}$ & $\begin{array}{l}\text { Critical Perspectives } \\
\text { on Accounting }\end{array}$ & 146 \\
\hline 4 & Dumay, John & 2016 & $\begin{array}{l}\text { A critical reflection on } \\
\text { the future of intellectual } \\
\text { capital: From reporting } \\
\text { to disclosure }\end{array}$ & $\begin{array}{c}\text { Journal of } \\
\text { Intellectual Capital }\end{array}$ & 128 \\
\hline 5 & Adams, Carol A. & 2015 & $\begin{array}{l}\text { The International } \\
\text { Integrated Reporting } \\
\text { Council: A call to action }\end{array}$ & $\begin{array}{l}\text { Critical Perspectives } \\
\text { on Accounting }\end{array}$ & 125 \\
\hline 6 & Brown, Judy; Dillard, Jesse & 2014 & $\begin{array}{l}\text { Integrated reporting: On } \\
\text { the need for broadening } \\
\text { out and opening up }\end{array}$ & $\begin{array}{l}\text { Accounting Auditing and } \\
\text { Accountability Journal }\end{array}$ & 125 \\
\hline
\end{tabular}


Table 5. Cont.

\begin{tabular}{|c|c|c|c|c|c|}
\hline Ranking & Author & Year & Title & Journal & Citations \\
\hline 7 & $\begin{array}{l}\text { Stubbs, Wendy; } \\
\text { Higgins, Colin }\end{array}$ & 2014 & $\begin{array}{l}\text { Integrated reporting and } \\
\text { internal mechanisms } \\
\text { of change }\end{array}$ & $\begin{array}{l}\text { Accounting Auditing and } \\
\text { Accountability Journal }\end{array}$ & 124 \\
\hline 8 & $\begin{array}{l}\text { Frías-Aceituno, Jose V.; } \\
\text { Rodríguez-Ariza, Lazaro; } \\
\text { García-Sánchez, Isabel M. }\end{array}$ & 2014 & $\begin{array}{l}\text { Explanatory factors of } \\
\text { integrated sustainability } \\
\text { and financial reporting }\end{array}$ & $\begin{array}{c}\text { Business Strategy and the } \\
\text { Environment }\end{array}$ & 119 \\
\hline 9 & $\begin{array}{l}\text { Beattie, Vivien; Smith, } \\
\text { Sarah Jane }\end{array}$ & 2013 & $\begin{array}{l}\text { Value creation and } \\
\text { business models: } \\
\text { Refocusing the } \\
\text { intellectual } \\
\text { capital debate }\end{array}$ & British Accounting Review & 118 \\
\hline 10 & $\begin{array}{l}\text { Frías-Aceituno, J. V.; } \\
\text { Rodríguez-Ariza, L.; } \\
\text { García-Sánchez, I. M. }\end{array}$ & 2013 & $\begin{array}{l}\text { Is integrated reporting } \\
\text { determined by a } \\
\text { country's legal system? } \\
\text { An exploratory study }\end{array}$ & $\begin{array}{l}\text { Journal of Cleaner } \\
\text { Production }\end{array}$ & 115 \\
\hline 11 & $\begin{array}{c}\text { García-Sánchez, } \\
\text { Isabel-Maria; } \\
\text { Rodríguez-Ariza, Lazaro; } \\
\text { Frías-Aceituno, } \\
\text { Jose-Valeriano }\end{array}$ & 2013 & $\begin{array}{l}\text { The cultural system and } \\
\text { integrated reporting }\end{array}$ & $\begin{array}{c}\text { International } \\
\text { Business Review }\end{array}$ & 109 \\
\hline 12 & $\begin{array}{c}\text { Cheng, Mandy; Green, } \\
\text { Wendy; Conradie, Pieter; } \\
\text { Konishi, Noriyuki; } \\
\text { Romi, Andrea }\end{array}$ & 2014 & $\begin{array}{l}\text { The International } \\
\text { Integrated Reporting } \\
\text { Framework: Key issues } \\
\text { and future } \\
\text { research Opportunities }\end{array}$ & $\begin{array}{l}\text { Journal of International } \\
\text { Financial Management } \\
\text { and Accounting }\end{array}$ & 104 \\
\hline
\end{tabular}

Source: prepared by authors with data from Web of Science (2019).

4.2. Main Components in Scientific Production: Authors, Journals, Institutions, Countries, and Key Words

\subsubsection{Main Authors}

Within the body of the 268 articles published in WoS around the concept of integrated reporting, 504 authors are recognized as single authors or coauthors with a high concentration, as seen by analyzing the percentage of citations of the 10 most influential authors $(49.2 \%)$. In accordance with the data in Table 6, the most influential author, TC-IR, is Isabel García from the University of Salamanca, who published 7 articles related to integrated reporting, which together were cited 577 times, corresponding to $9.8 \%$ of the total citations. García has 4 of the 40 most influential articles considering the $h$ index of the search vector. The second most influential author is Lázaro Rodríguez of the University of North Carolina, who, with 4 articles related to integrated reporting, had 532 citations. Rodríguez has 4 of the 40 most influential articles of all time on the topic. Table 5 shows the 10 most influential authors in integrated reporting. 
Table 6. Most influential authors.

\begin{tabular}{|c|c|c|c|c|c|c|c|c|c|}
\hline Ranking & Author & Institution & TP-IR & TC-IR & $\%$ & HA & TP & TC & $\mathrm{T} 40$ \\
\hline 1 & Garcia, Isabel & University of Salamanca & 7 & 577 & $11.1 \%$ & 32 & 144 & 3.285 & 4 \\
\hline 2 & Rodriguez, Lázaro & University of North Carolina & 4 & 532 & $10.2 \%$ & 12 & 45 & 1.070 & 4 \\
\hline 3 & De Villiers, Charl & University of Auckland & 8 & 355 & $6.8 \%$ & 22 & 66 & 1.897 & 3 \\
\hline 4 & Maroun, Warren & University of the Witwatersrand & 19 & 336 & $6.4 \%$ & 12 & 54 & 524 & 2 \\
\hline 5 & Frías, José & University of Granada & 3 & 307 & $5.9 \%$ & 11 & 20 & 842 & 3 \\
\hline 6 & Unerman, Jeffrey & Lancaster University & 4 & 287 & $5.5 \%$ & 16 & 24 & 1.236 & 1 \\
\hline 7 & Dumay, John & Macquarie University & 12 & 285 & $5.5 \%$ & 30 & 94 & 3.036 & 2 \\
\hline 8 & Melloni, Gaia & University of Lausanne & 8 & 283 & $5.4 \%$ & 7 & 11 & 283 & 4 \\
\hline 9 & Simnett, Roger & University of New South Wales, Sydney & 5 & 266 & $5.1 \%$ & 18 & 30 & 1.766 & 3 \\
\hline 10 & Higgins, Colin & Deakin University & 4 & 243 & $4.7 \%$ & 10 & 53 & 1.431 & 2 \\
\hline
\end{tabular}

Abbreviations: TP-IR: total articles of author; TC-IR: total citations of the author of the articles; HA: h index of the author; TP: total articles of author; TC: total of citations of the author; T40: total articles of the author that are in the 40 most influential articles published in the period under study. Source: prepared by authors with data from Web of Science (2019).

\subsubsection{Main Journals}

In terms of main journals, the 268 articles were published in 83 indexed journals in WoS, with 10 of these journals accounting for 132 articles, equivalent to $49.3 \%$ of the total publications. Each article is cited an average of 25.31 times, totaling 3341 citations and with an $h$ index of 32. Table 7 shows the details of the 10 most cited journals.

Table 7. Journals of Web of Science in which scientific production is generated.

\begin{tabular}{|c|c|c|c|c|c|c|c|c|}
\hline Ranking & Journal & NP & $\%$ & PC-IR & H-IR & TC-IR & FI 5Y & Q \\
\hline 1 & Journal of Intellectual Capital & 23 & $6.71 \%$ & 16.26 & 9 & 383 & 3.744 & Q1 \\
\hline 2 & $\begin{array}{c}\text { Accounting Auditing and Accountability } \\
\text { Journal }\end{array}$ & 22 & $6.41 \%$ & 42.27 & 14 & 930 & 4.397 & Q1 \\
\hline 3 & Meditari Accountancy Research & 21 & $6.12 \%$ & 22.62 & 11 & 475 & - & - \\
\hline 4 & $\begin{array}{c}\text { Sustainability Accounting Management and } \\
\text { Policy Journal }\end{array}$ & 14 & $4.08 \%$ & 17.43 & 5 & 244 & 1.745 & Q2 \\
\hline 5 & Business Strategy and the Environment & 13 & $3.79 \%$ & 21.77 & 7 & 283 & 7.557 & Q1 \\
\hline 6 & $\begin{array}{c}\text { Corporate Social Responsibility and } \\
\text { Environmental Management }\end{array}$ & 9 & $2.62 \%$ & 36.00 & 6 & 324 & 7.131 & Q1 \\
\hline 7 & Journal of Management Governance & 9 & $2.62 \%$ & 4.44 & 2 & 40 & - & - \\
\hline 8 & Critical Perspectives on Accounting & 8 & $2.33 \%$ & 47.38 & 7 & 379 & 3.396 & Q1 \\
\hline 9 & Journal of Applied Corporate Finance & 7 & $2.61 \%$ & 12.57 & 4 & 88 & - & - \\
\hline \multirow[t]{2}{*}{10} & Australian Accounting Review & 6 & $2.24 \%$ & 26.50 & 5 & 159 & 1.450 & Q3 \\
\hline & Total & 132 & $49.254 \%$ & 25.31 & 32 & 3.341 & 4.662 & \\
\hline
\end{tabular}

Abbreviations: NP: total of articles about integrated reporting in the journal; \%: percentage of articles over total articles about integrated reporting; PC-IR: average of citations per article in the search vectors; H-IR: $h$ index only with the search vectors; TC-SQ: total citations only with the search vectors; FI Y5: factor of impact of the journal in the last 5 years; Q: quartile of the journal. Source: prepared by authors with data from Web of Science (2019).

The journal with the most articles, NP, is the Journal of Intellectual Capital by Emerald Group Publishing, with a total of 23 articles and number of citations per author, TC-IR, of 383. The journals with the next most articles are Accounting Auditing and Accountability Journal and Meditari Accountancy Research with 22 and 21 publications, respectively. In relation to the number of citations per author, Accounting Auditing and Accountability Journal, Meditari Accountancy Research, and the Journal of Intellectual Capital have 930, 475, and 383 citations, respectively. In relation to impact factor, FI 5Y, Business Strategy and the Environment, and Corporate Social Responsibility and Environmental Management are seen as the most relevant journals.

\subsubsection{Institutions with Largest Amount of Scientific Production}

In terms of the affiliation of the 268 articles in the area of integrated reporting, only 8 institutions of a total of 303 account for $29.1 \%$ of scientific production. In addition, South African institutions have a total of 40 publications, equivalent to $14.93 \%$ of the total. This can be explained by the longer experience, mandatory obligation, and use of integrated 
reporting in South Africa (see Table 8). This result is consistent with [36,49], who associate its increasing use with the significant and positive effect between information disclosed in integrated reports and financial performance.

Table 8. Institutions with largest amount of scientific production according to author affiliation.

\begin{tabular}{|c|c|c|c|c|c|c|c|c|}
\hline Ranking & Institutions & Country & NP & $\%$ & h IR & PC-IR & TC-IR & $\mathrm{AC}$ \\
\hline 1 & University of the Witwatersrand & South Africa & 22 & $8.21 \%$ & 9 & 15.64 & 344 & 185 \\
\hline 2 & University of Pretoria & South Africa & 18 & $6.72 \%$ & 10 & 34.83 & 627 & 368 \\
\hline 3 & Macquarie University & Australia & 15 & $5.60 \%$ & 7 & 21.47 & 322 & 240 \\
\hline 4 & University of Auckland & New Zealand & 9 & $3.36 \%$ & 5 & 24.33 & 219 & 147 \\
\hline 5 & $\begin{array}{l}\text { Ministry of Education Science } \\
\text { of Ukraine }\end{array}$ & Ukraine & 6 & $2.24 \%$ & 1 & 0.5 & 3 & 2 \\
\hline 6 & $\begin{array}{c}\text { University of New South } \\
\text { Wales Sydney }\end{array}$ & Australia & 6 & $2.24 \%$ & 5 & 61.83 & 371 & 271 \\
\hline 7 & University of Valencia & Spain & 6 & $2.24 \%$ & 5 & 18 & 108 & 91 \\
\hline \multirow[t]{2}{*}{8} & University of Verona & Italy & 6 & $2.24 \%$ & 5 & 22.67 & 136 & 116 \\
\hline & Total & & 78 & $29.1 \%$ & 22 & 22.62 & 1.764 & 741 \\
\hline
\end{tabular}

Abbreviations: R: ranking; NP: total of articles only with integrated reporting; \%: percentage of articles over total of articles on integrated reporting; h IR: h index only with the search vectors; PC-IR: average of citations per article for the search vectors; TC-IR: total citations only with the search vectors; AC: quantity of articles in which they are cited. Source: data from Web of Science (2019).

The South African institution with the largest number of publications is the University of the Witwatersrand with 22 articles. However, the University of Pretoria shows greater impact in relation to citations, TC-IR, with 627 mentions. Its h IR index is 10, which means that at least 10 of its articles were cited at least 10 times, and it has a larger number of articles in which they are cited, AC, of 368 . Following bibliometric analysis, five clusters were estimated according to the number of citations related to the institution. A pruning mechanism was considered in this estimation, with a minimum of three articles per institution. The obtained clusters are shown in Table 9, and their respective graphs in Figure 2.

Table 9. Cluster of most-cited institutions.

\begin{tabular}{cccc}
\hline Cluster 1 & Cluster 2 & Cluster 3 & Cluster 5 \\
\hline Bucharest Univ Econ Studies & Ebs Univ Wirtschaft and Recht & Bocconi Univ & Int Islamic Univ Malaysia \\
Deakin Uni & Murry State Univ & Univ East Anglia & Rmit Univ \\
Harvard Sch Business & Univ Lum Jean Monnet & Univ Ferrara & Swinburne Univ Technol \\
Royal Holloway Univ London & Univ New S Wales & Univ Verona & \\
Univ Auckland & Univ Salamanca & \\
Univ Durham & Univ Valencia & Cluster 4 & Aalborg Univ \\
Univ Melbourne & Univ Valle & Macquarie Univ & Monash Univ \\
Univ Pretoria & Univ Vigo & Univ Bologna & \\
Univ Sydney & & & \\
Univ Witwatersrand & & & \\
\hline
\end{tabular}




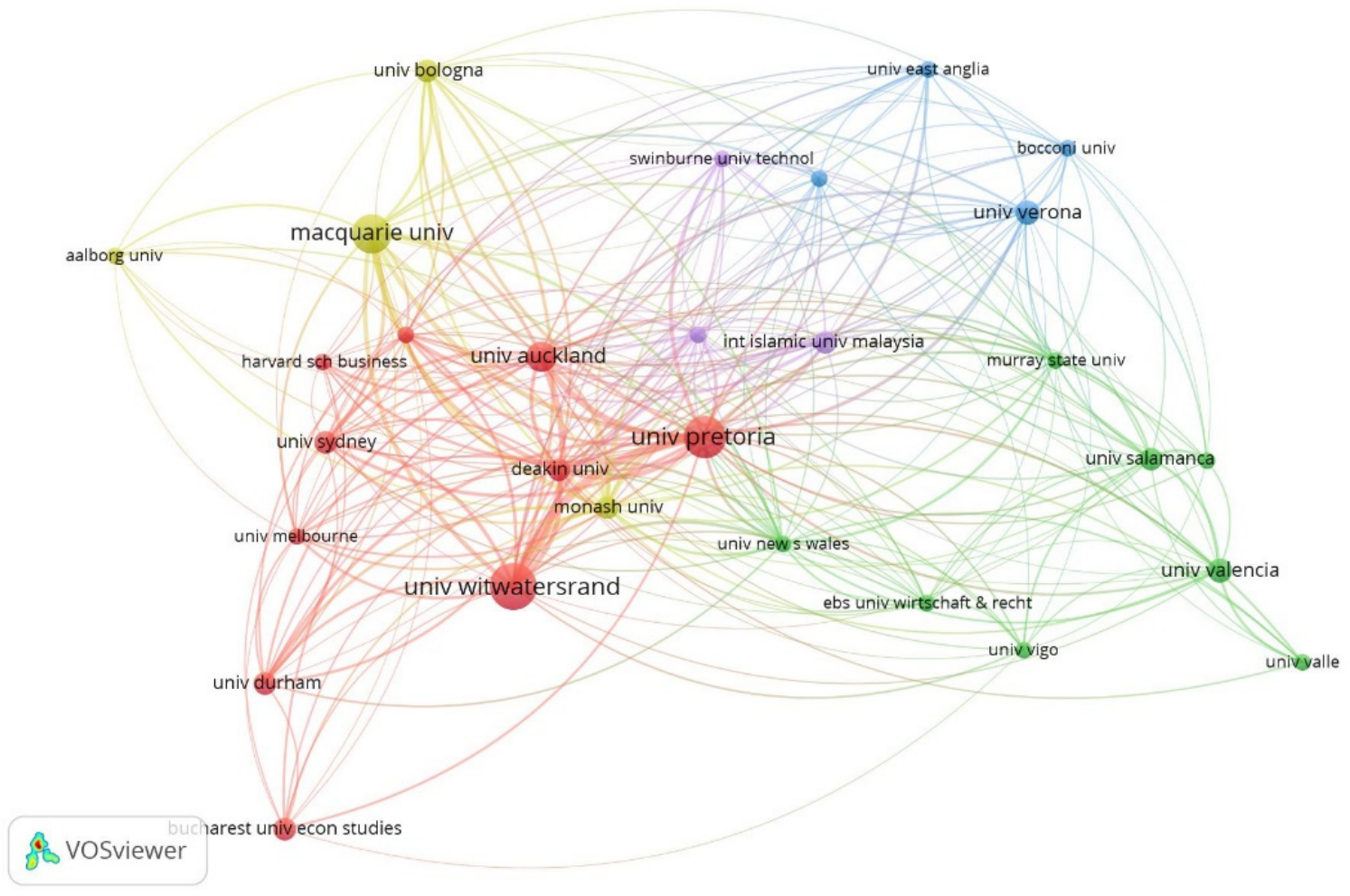

Figure 2. Clusters of the most cited institutions. Source: prepared by the authors with VOSviewer software.

The graph in Figure 2 shows five clusters. The first cluster contains 10 institutions and is represented by red, where the predominant institution is the University of Pretoria with 634 citations and relationships with 370 other institutions. In addition, a second cluster is represented by green. The institution that predominates in this cluster is the University of New South Wales, with 289 citations and 112 relationships with other institutions. The third cluster contains four institutions and is represented by blue. In this cluster, the predominant institution is the University of Verona, with 136 citations and 84 connections with other institutions. The fourth cluster contains four institutions and is represented by yellow. In this cluster, Monash University predominates with 375 citations and relationships with 214 institutions. Lastly, the fifth cluster considers three institutions and is represented by purple. In this cluster, the International Islamic University Malaysia predominates with 105 citations and relationships with 78 institutions.

\subsubsection{Countries with the Largest Amount of Scientific Production}

In terms of the countries that carry out the largest amount of scientific production according to the affiliation of the authors, considering the 268 analyzed articles, $70.9 \%$ of the articles are concentrated in 5 countries out of 51 that generated at least 1 article related to the topic of the search, integrated reporting. Table 10 shows the 10 countries that have developed and published more than 10 articles related to integrated reporting. These 10 countries together have an $h$ index of 38 with average citations of 21.81, total citations of 4536, and 1473 articles that cite this set of countries. 
Table 10. Countries associated with scientific production according to author affiliation.

\begin{tabular}{cccccccc}
\hline Ranking & Country/Region & NP & $\mathbf{\%}$ & h IR & PC-IR & TC-IR & AC \\
\hline 1 & Italy & 46 & 17.16 & 13 & 11.76 & 541 & 295 \\
2 & South Africa & 45 & 16.79 & 16 & 20.96 & 943 & 441 \\
3 & Australia & 40 & 14.93 & 19 & 33.80 & 1.352 & 586 \\
4 & England & 36 & 13.43 & 16 & 26.31 & 947 & 537 \\
5 & US & 23 & 8.58 & 12 & 21.87 & 503 & 379 \\
6 & Spain & 18 & 6.72 & 10 & 36.32 & 652 & 399 \\
7 & New Zealand & 16 & 5.97 & 11 & 48.38 & 774 & 389 \\
8 & Germany & 13 & 4.85 & 8 & 18.38 & 239 & 175 \\
9 & France & 10 & 3.73 & 5 & 8.60 & 86 & 80 \\
10 & Scotland & 10 & 3.73 & 7 & 25.80 & 258 & 233 \\
& Data of the set & 208 & 77.6 & 38 & 21.81 & 4.536 & 1.473
\end{tabular}

Abbreviations: R: ranking; NP: total of papers related to integrated reporting; \%: percentage of papers of search vectors over total of articles of the same search vectors; $h$ IR: $h$ index only in integrated reporting; PC-IR: average of citations per paper over search vectors; TC-IR: total of citations only with the search vectors; AC: quantity of articles in which they are cited. Source: data from Web of Science (2019).

Italy has the largest number of publications, NP, with 46 articles related to integrated reporting. Australia has the largest number of cited articles, TC-IR, at 1352, placing it as the most influential country with respect to integrated-reporting research. Australia also has a higher $h$ index and quantity of articles in which it is cited, AC, of 19 and 586, respectively. New Zealand has 16 articles and the largest average citations per article, reaching 48.38 citations per article. Italy is the country with the highest number of publications, $\mathrm{NP}, 46$ articles related to integrated reporting, followed by South Africa with 45 published articles, which is consistent with [49].

In relation to coauthorship by country, a total of 10 clusters are observed, which allows for differentiation of the contribution of each cluster (see Table 11). Figure 3 shows the relative importance of each country. Specifically, it is possible to observe the relative importance of South Africa, which belongs to Cluster 8; Australia, which belongs to Cluster 9; Italy, which belongs to Cluster 10; and Germany, which belongs to Cluster 4. The relative size of each figure in the graph is proportional to the quantity of coauthorships carried out by authors assigned to those countries.

Table 11. Cluster of coauthorship between countries.

\begin{tabular}{ccccc}
\hline Cluster $\mathbf{1}$ & Cluster $\mathbf{2}$ & Cluster 3 & Cluster 4 & Cluster 5 \\
\hline Canada & Brazil & Denmark & Germany & Indonesia \\
France & Japan & Norway & India \\
Greece & Portugal & Scotland & Malaysia \\
Netherlands & US & Sweden & Switzerland & \\
Turkey & & Cluster $\mathbf{8}$ & Cluster 9 & Cluster 10 \\
\hline Cluster 6 & Cluster 7 & New Zealand & Australia & Italy \\
Colombia & England & Russia & Singapore \\
Spain & Saudi Arabia & South Africa & &
\end{tabular}

Source: prepared by the authors with VOSviewer software. 


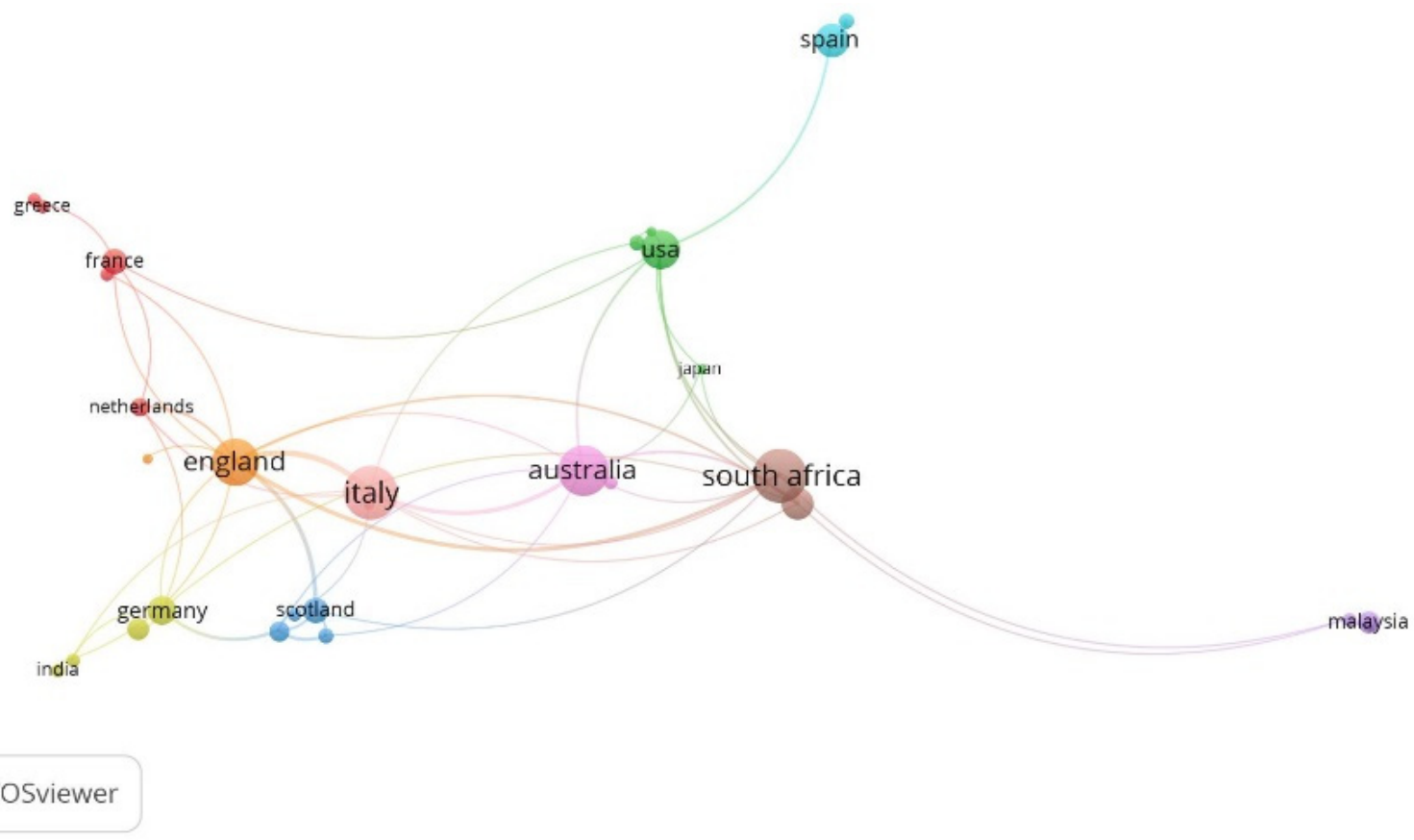

Figure 3. Most-cited coauthorships by country. Source: prepared by authors with VOSviewer software.

\subsubsection{Bibliometric Analysis of Keywords}

Of the 454 keywords plus included in the articles published in WoS, 116 appeared more than 3 times, which allows for them to be grouped in 7 clusters (see Table 12). Table 13 provides a summary of the most utilized keywords in the research associated with integrated reporting, and Figure 4 shows the importance and relative use of the keywords in more detail.

Table 12. Clusters of keywords plus.

\begin{tabular}{|c|c|}
\hline $\begin{array}{l}\text { Cluster } 1 \\
28 \text { items } \\
\quad(\text { red })\end{array}$ & $\begin{array}{l}\text { Agency costs_-Association-Attributes-Board composition-Commercial banks-Corporate disclosure-Corporate } \\
\text { governance-Corporate social responsibility-Directors-Earnings-Earnings management-Empirical } \\
\text { evidence-Environmental performance-Equity-Financial disclosure-Financial performance-Firm-Gender } \\
\text { diversity-Governance-Information asymmetry-Institutional investors-Intellectual capital disclosure-Investor } \\
\text { protection-Ownership_-Social responsibility-Social responsibility disclosure-Value relevance-Voluntary disclosure. }\end{array}$ \\
\hline $\begin{array}{l}\text { Cluster } 2 \\
23 \text { items } \\
\text { (green) }\end{array}$ & $\begin{array}{l}\text { Accountability-Balanced scorecard-Challenges-Communication-Competitive advantage-Corporate } \\
\text { sustainability-Decision making-Diffusion-Exploration-Firm } \\
\text { value-Future-Implementation-Indicators-Information-Insights-Investors-Management-Methodology- } \\
\text { Organization-Perspectives-Strategy-Thinking-UK. }\end{array}$ \\
\hline $\begin{array}{l}\text { Cluster } 3 \\
21 \text { items } \\
\text { (blue) }\end{array}$ & $\begin{array}{r}\text { Adoption-Business-Corporate-Engagement-Environmental disclosure-Environmental } \\
\text { disclosures-Firms-Impression } \\
\text { management-Institutionalization-Legitimacy-Model-Myth-Organizations-Performance-Perspective-Power-M - } \\
\text { Responsibility-Risk-Stakeholder-Sustainable development-Valuation }\end{array}$ \\
\hline $\begin{array}{l}\text { Cluster } 4 \\
20 \text { items } \\
\text { (yellow) }\end{array}$ & $\begin{array}{l}\text { Accounting information-Audit quality-Australia-Cost-CSR-Determinants-Economic consequence-Forecast } \\
\text { accuracy-Impact-Isomorphism-Market-Nonfinancial disclosure-Perceptions-Quality - } \\
\text { Returns-Standards-Statements-Sustainability reports-Transparency-Voluntary nonfinancial disclosure. }\end{array}$ \\
\hline $\begin{array}{l}\text { Cluster } 5 \\
14 \text { items } \\
\text { (purple) }\end{array}$ & $\begin{array}{l}\text { Accounting research-Disclosures-Framework-Future } \\
\text { research-Gaps-Mechanisms-Narratives-Need-Opportunities-South } \\
\text { Africa-Sustainability-System-Systems-Value creation. }\end{array}$ \\
\hline $\begin{array}{l}\text { Cluster } 6 \\
7 \text { items } \\
\text { (light blue) }\end{array}$ & Companies-Disclosure-Innovation-Intangibles-Knowledge-Reflections—Strategies. \\
\hline $\begin{array}{l}\text { Cluster } 7 \\
2 \text { items } \\
\text { (orange) }\end{array}$ & Assurance-Economic performance \\
\hline
\end{tabular}


\& VOSviewer

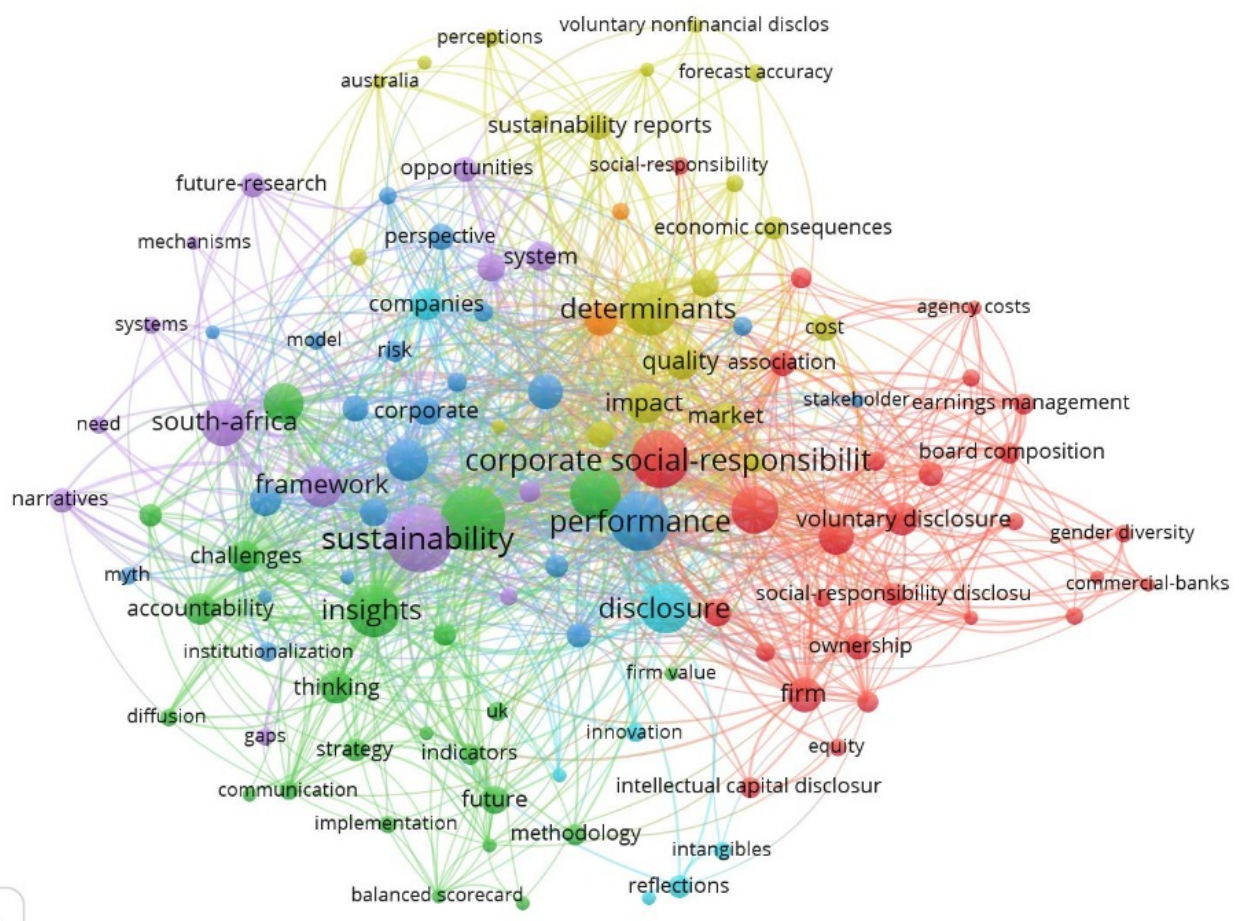

Figure 4. Keywords with greatest occurrence. Source: prepared by the authors with VOSviewer software.

Table 13 summarizes the 10 most utilized keywords in the research associated with integrated reporting: 'sustainability', with 57 occurrences in Cluster 5; 'management', with 54 occurrences in Cluster 2; 'performance', with 47 occurrences in Cluster 3; and 'corporate social responsibility', with 43 occurrences in Cluster 1.

Table 13. Clusters of co-occurrence in keywords plus.

\begin{tabular}{ccc}
\hline Ranking & Keyword & Occurrence \\
\hline 1 & Sustainability & 57 \\
2 & Management & 54 \\
3 & Performance & 47 \\
4 & Corporate social responsibility & 43 \\
5 & Determinants & 38 \\
6 & Insights & 37 \\
7 & Information & 35 \\
8 & Disclosure & 33 \\
9 & Governance & 29 \\
10 & South Africa & 28 \\
\hline
\end{tabular}

Source: data from Web of Science (2019).

\section{Conclusions}

In general, the literature referring to the use of integrated reporting has grown since 2011. Integrated reporting complements current financial reports that companies prepare and publish, revealing the value of the information. Furthermore, journals that broadcast this new knowledge are, in the majority, the most productive and have the highest quality in their field, with a high scientific impact. These findings emphasize the growing consciousness of the importance of research on the topic of integrated reporting.

Our results also indicate the significant impact of the literature, as $84.97 \%$ of the articles were cited at least once, and $10.44 \%$ were cited more than 50 times. The works 
of [63], and [28] are the most cited with 205 and 185 citations, respectively. On reviewing the contribution of the most influential authors in integrated reporting, this study highlights García, Rodríguez, and De Villiers with total citations, TC-IR, of 577, 532, and 355, respectively. Even though research in this field is globally spread, almost $77.6 \%$ of the academic articles are from developed countries. The most influential countries are Italy, Australia, the United Kingdom, and the United States with $17.16 \%, 14.93 \%, 13.43 \%$, and $8.58 \%$, respectively. This shows that the development of this type of research tends to be stronger in developed countries than in emerging economies, which creates new research opportunities in the future in emerging economies.

In terms of used journals to publish research on integrated reporting, three journals stand out: the Journal of Intellectual Capital, Accounting Auditing and Accountability Journal, and Meditari Accountancy Research with 6.71\%, 6.41\%, and 6.12\%, respectively. Furthermore, almost $50 \%$ of the published works are concentrated in 10 main journals. In relation to the most influential institutions, two South African universities stand out: the University of the Witwatersrand and the University of Pretoria, although this result is likely due to the mandatory preparation of integrated reporting for listed firms in South Africa [64]. Furthermore, this result shows the scarcity of research in American countries because they do not appear among the most influential countries. Lastly, in relation to used keywords, a high level of interconnections was observed, with 'sustainability' and 'management' being the most utilized.

One of the main limitations identified in this research is giving a general view of the integrated-reporting literature. However, it is possible to deepen the use of integrated reporting by recognizing its effect on the performance of companies.

As future research, we propose to recognize the effect of integrated reporting on the performance of companies and observe its impact in some countries in Latin America, because companies are expected to adopt this reporting to improve decision-making processes.

The main contribution of this research is to synthesize the published knowledge and to offer an updated discussion on research undertaken on integrated reporting, obtained from the most important scientific journals. This study offers researchers updated bibliometric analysis to support future research. Through the analysis carried out, lines for future research were established, setting out scientific criteria to make the efforts of academics working in the area of integrated reporting more efficient. It also serves as a basis for comparison with other academic databases.

Author Contributions: All of the authors contributed to conceptualization, formal analysis, investigation, methodology and writing and editing the original draft. All authors have read and agreed to the published version of the manuscript.

Funding: This research received no external funding.

Institutional Review Board Statement: Not applicable.

Informed Consent Statement: Not applicable.

Data Availability Statement: The data presented in this study are available on request from the corresponding author.

Conflicts of Interest: The authors declare no conflict of interest.

\section{References}

1. García-Benau, M.A.; Sierra, L.; Zorio, A. Financial crisis impact on sustainability reporting. Manag. Decis. 2013, 51, 1-21. [CrossRef]

2. Jennings, M.M. A primer on Enron: Lessons from a perfect storm of financial reporting, corporate governance and ethical culture failures. Calif. West. Law Rev. 2003, 39, 163-262.

3. Mans-Kemp, N.; Van der Lugt, C.T. Linking integrated reporting quality with sustainability performance and financial performance in South Africa. South Afr. J. Econ. Manag. Sci. 2020, 23, a3572.

4. Brown, J.; Dillard, J. Integrated reporting: On the need for broadening out and opening up. Account. Audit. Account. J. 2014, 27, 1120-1156. [CrossRef] 
5. Slack, R.; Campbell, E. Meeting Users' Information Needs: The Use and Usefulness of Integrated Reporting. The Association of Chartered Certified Accountants. 2016. Available online: https://www.accaglobal.com/content/dam/ACCA_Global/Technical/ integrate/pi-useusefulness-ir.pdf (accessed on 3 March 2021).

6. De Villiers, C.; Hsiao, P.C.K.; Maroun, W. Developing a conceptual model of influences around integrated reporting, new insights and directions for future research. Meditari Account. Res. 2017, 25, 450-460. [CrossRef]

7. Dumay, J. A critical reflection on the future of intellectual capital: From reporting to disclosure. J. Intellect. Cap. 2016, 17, 168-184. [CrossRef]

8. Klasa, A. Sustainable Finance: Integrated Reporting Offers Fix for Insufficient Status Quo. Financial Times. Available online: https:/ / www.ft.com/content/e0eb2a72-ddfb-11e8-b173-ebef6ab1374a (accessed on 5 December 2018).

9. Zhou, S.; Simnett, R.; Green, W. Does integrated reporting matter to the capital market? ABACUS 2017, 53, 94-132. [CrossRef]

10. Beck, C.; Dumay, J.; Frost, G. In pursuit of a 'single source of truth': From threatened legitimacy to integrated reporting. J. Bus. Ethics 2017, 141, 191-205. [CrossRef]

11. Caglio, A.; Melloni, G.; Perego, P. Informational content and assurance of textual disclosures: Evidence on integrated reporting. Eur. Account. Rev. 2020, 29, 55-83. [CrossRef]

12. De Villiers, C.; Venter, E.R.; Hsiao, P.C.K. Integrated reporting: Background, measurement issues, approaches and an agenda for future research. Account. Financ. 2017, 57, 937-959. [CrossRef]

13. Melloni, G.; Caglio, A.; Perego, P. Saying more with less? Disclosure conciseness, completeness and balance in integrated reports. J. Account. Public Policy 2017, 36, 220-238. [CrossRef]

14. Nicolò, G.; Zanellato, G.; Tiron-Tudor, A. Integrated reporting and European state-owned enterprises: A disclosure analysis pre and post 2014/95/EU. Sustainability 2020, 12, 1908. [CrossRef]

15. Atkins, J.; Maroun, W. Integrated reporting in South Africa in 2012: Perspectives from South African institutional investors. Meditari Account. Res. 2015, 23, 197-221. [CrossRef]

16. Girella, L.; Rossi, P.; Zambon, S. Exploring the firm and country determinants of the voluntary adoption of integrated reporting. Bus. Strategy Environ. 2019, 28, 1323-1340. [CrossRef]

17. Dumay, J.; Bernardi, C.; Guthrie, J.; Demartini, P. Integrated reporting: A structured literature review. Account. Forum 2016, 40, 166-185. [CrossRef]

18. Velte, P.; Stawinoga, M. Integrated reporting: The current state of empirical research, limitations and future research implications. J. Manag. Control. 2017, 28, 275-320. [CrossRef]

19. Wahl, A.; Charifzadeh, M.; Diefenbach, F. Voluntary adopters of integrated reporting-Evidence on forecast accuracy and firm value. Bus. Strategy Environ. 2020, 29. [CrossRef]

20. Eccles, R.; Krzus, M.; Ribot, S. Meaning and momentum in the integrated reporting movement. J. Appl. Corp. Financ. 2015, 27, 8-17. [CrossRef]

21. Flower, J. The international integrated reporting council: A story of failure. Crit. Perspect. Account. 2015, 27, 1-17. [CrossRef]

22. Gibassier, D.; Adams, C.A.; Jerome, T. Integrated Reporting and the Capitals' Diffusion. French Accounting Standard Setter (Autorité des Normes Comptables). 2019. Available online: https:/ /ssrn.com/abstract=3429709 (accessed on 27 April 2021).

23. Atkins, J.F.; Solomon, A.; Norton, S.; Joseph, N.L. The emergence of integrated private reporting. Meditari Account. Res. 2015, 23, 28-61. [CrossRef]

24. International Reporting Committee of South Africa. Framework for Integrated Reporting and the Integrated Report: Discussion Paper. 2011. Available online: http:/ /integratedreportingsa.org/ircsa/wp-content/uploads/2017/05/IRC-of-SA-IntegratedReporting-Guide-Jan-11.pdf (accessed on 27 April 2021).

25. Camodeca, R.; Almici, A.; Sagliaschi, U. Sustainability disclosure in integrated reporting: Does it matter to investors? A cheap talk approach. Sustainability 2018, 10, 4393. [CrossRef]

26. Cheng, M.; Green, W.; Conradie, P.; Konishi, N.; Romi, A. The international integrated reporting framework: Key issues and future research opportunities. J. Int. Financ. Manag. Account. 2014, 25, 90-119. [CrossRef]

27. Eccles, R.; Saltzman, D. Achieving sustainability through integrated reporting. Stanf. Soc. Innov. Rev. $2011,9,56-61$.

28. Frías-Aceituno, J.V.; Rodríguez-Ariza, L.; García-Sánchez, I.M. The role of the board in the dissemination of integrated corporate social reporting. Corp. Soc. Responsib. Environ. Manag. 2013, 20, 219-233. [CrossRef]

29. Adams, C.A. The international integrated reporting council: A call to action. Crit. Perspect. Account. 2015, 27, 23-28. [CrossRef]

30. Frías-Aceituno, J.V.; Rodríguez-Ariza, L.; García-Sánchez, I.M. Explanatory factors of integrated sustainability and financial reporting. Bus. Strategy Environ. 2014, 23, 56-72. [CrossRef]

31. Barth, M.E.; Cahan, S.F.; Chen, L.; Venter, E.R. The economic consequences associated with integrated report quality: Capital market and real effects. Account. Organ. Soc. 2017, 62, 43-64. [CrossRef]

32. Flores, E.; Fasan, M.; Mendes-da-Silva, W.; Oliveira Sampaio, J. Integrated reporting and capital markets in an international setting: The role of financial analysts. Bus. Strategy Environ. 2019, 28, 1465-1480. [CrossRef]

33. Bernardi, C.; Stark, A.W. Environmental, social and governance disclosure, integrated reporting, and the accuracy of analyst forecasts. Br. Account. Rev. 2018, 50, 16-31. [CrossRef]

34. Lee, K.W.; Yeo, G.H.H. The association between integrated reporting and firm valuation. Rev. Quant. Financ. Account. 2016, 47, 1221-1250. [CrossRef] 
35. Cooray, T.; Gunarathne, N.; Senaratne, S. Does corporate governance affect the quality of integrated reporting? Sustainability 2020, 12, 4262. [CrossRef]

36. Cooray, T.; Senaratne, S.; Gunarathne, N.; Herath, R.; Samudrage, D. Does integrated reporting enhance the value relevance of information? Evidence from Sri Lanka. Sustainability 2020, 12, 4262. [CrossRef]

37. International Integrated Reporting Council. The International Framework. Integrated Reporting Committee. 2013. Available online: www.theiirc.org (accessed on 27 April 2021).

38. Sinnewe, E.; Yao, T.; Zaman, M. Informing or obfuscating stakeholders: Integrated reporting and the information environment. Bus. Strategy Environ. 2021, 1-14. [CrossRef]

39. Lai, A.; Melloni, G.; Stacchezzini, R. Corporate Sustainable Development: Is "Integrated Reporting" a Legitimation Strategy? Bus. Strategy Environ. 2016, 25, 165-177. [CrossRef]

40. Reimsbach, D.; Hahn, R.; Gürtürk, A. Integrated Reporting and Assurance of Sustainability Information: An Experimental Study on Professional Investors' Information Processing. Eur. Account. Rev. 2018, 27, 559-581. [CrossRef]

41. Tlili, M.; Othman, H.B.; Hussainey, K. Does integrated reporting enhance the value relevance of organizational capital? Evidence from the South African context. J. Intellect. Cap. 2019, 20, 642-661. [CrossRef]

42. Churet, C.; Eccles, R.G. Integrated Reporting, Quality of Management, and Financial Performance. J. Appl. Corp. Financ. 2014, 26, 56-64. [CrossRef]

43. Matemane, R.; Wentzel, R. Integrated reporting and financial performance of South African listed banks. Bus. Perspect. 2019, 14, 128-139. [CrossRef]

44. Rivera- Arrubia, Y.; Zorio-Grima, A.; García-Benau, M.A. El concepto de informe integrado como innovación en reporting corporativo. J. Innov. Knowl. 2016, 1, 144-155. [CrossRef]

45. Jensen, J.C.; Berg, N. Determinants of Traditional Sustainability Reporting Versus Integrated Reporting. An Institutionalist Approach. Bus. Strategy Environ. 2012, 25, 299-316. [CrossRef]

46. Hamad, S.; Umar Draz, M.; Lai, F.-W. The impact of corporate governance and sustainability reporting on integrated reporting: A conceptual framework. SAGE Open 2020, 1-15. [CrossRef]

47. Adhikariparajuli, M.; Hassan, A.; Fletcher, M.; Elamer, A. Integrated reporting in higher education: Insights from Scotland, Northern Ireland and Wales. Soc. Responsib. J. 2019. In print. [CrossRef]

48. Stent, W.; Dowler, T. Early assessments of the gap between integrated reporting and current corporate reporting. Meditari Account. Res. 2015, 23, 92-117. [CrossRef]

49. Ahmed Haji, A.; Anifowose, M. The trend of integrated reporting practice in South Africa: Ceremonial or substantive? Sustain Account. Manag. Policy J. 2016, 7, 190-224. [CrossRef]

50. Al Amosh, H.; Mansor, N. The implications of ownership structure on the environmental disclosure in Jordan. Int. J. Acad. Res. Bus. Soc. Sci. 2020, 10, 330-346. [CrossRef]

51. Omran, M.; Zaid, M.; Dwekat, A. The relationship between integrated reporting and corporate environmental performance: A green trial. Corp. Soc. Responsib. Environ. Manag. 2020, 28, 427-445. [CrossRef]

52. Obeng, V.; Ahmed, K.; Steven, F.C. Integrated reporting and agency costs: International evidence from voluntary adopters. Eur. Account. Rev. 2020. [CrossRef]

53. Massaro, M.; Dumay, J.; Guthrie, J. On the shoulders of giants: Undertaking a structured literature review in accounting. Account. Audit. Account. J. 2016, 29, 767-801. [CrossRef]

54. Ding, Y.; Chowdhury, G.; Foo, S. Bibliometric cartography of information retrieval research by using co-word analysis. Inf. Process. Manag. 2001, 37, 817-842. [CrossRef]

55. Van Eck, N.J.; Waltman, L. Software survey: VOSviewer, a computer program for bibliometric mapping. Scientometrics 2010, 84, 523-538. [CrossRef]

56. Pistoni, A.; Songini, L.; Bavagnoli, F. Integrated reporting quality: An empirical analysis. Corp. Soc. Responsib. Environ. Manag. 2018, 25, 489-507. [CrossRef]

57. Falagas, M.E.; Pitsouni, E.I.; Malietzis, G.A.; Pappas, G. Comparison of PubMed, Scopus, Web of Science, and Google Scholar: Strengths and weaknesses. Faseb J. 2008, 22, 338-342. [CrossRef] [PubMed]

58. Li, K.; Rollins, J.; Yan, E. Web of Science use in published research and review papers 1997-2017: A selective, dynamic, crossdomain, content-based analysis. Scientometrics 2018, 115, 1-20. [CrossRef] [PubMed]

59. Clarivate. Web of Science Group. 2020. Available online: https:/ / clarivate.com/webofsciencegroup / (accessed on 10 May 2021).

60. Zhao, X.; Wang, S.; Wang, X. Characteristics and trends of research on new energy vehicle reliability based on the web of science. Sustainability 2018, 10, 3560. [CrossRef]

61. Adams, S.; Simnett, R. Integrated reporting: An opportunity for Australia's not-for-profit sector. Aust. Account. Rev. 2011, 21, 292-301. [CrossRef]

62. Bornmann, L.; Ye, A.Y.; Ye, F.Y. Identifying "hot papers" and papers with "delayed recognition" in large-scale datasets by using dynamically normalized citation impact scores. Scientometrics 2018, 116, 655-674. [CrossRef]

63. De Villiers, C.; Rinaldi, L.; Unerman, J. Integrated reporting: Insights, gaps and an agenda for future research. Account. Audit. Account. J. 2014, 27, 1042-1067. [CrossRef]

64. Setia, N.; Abhayawansa, S.; Joshi, M.; Huynh, A.V. Integrated reporting in South Africa: Some initial evidence. Sustain. Account. Manag. Policy J. 2015, 6, 397-424. [CrossRef] 